\title{
Perbedaan Glukosa Serum dan Darah Plasma NaF dengan Penundaan 12 Jam pada Pasien Diabetes Melitus
}

\author{
Elfred Rinaldo Kasimo \\ Program Studi Teknologi Laboratorium Medis, Fakultas Ilmu Kesehatan, Universitas Kadiri \\ J1. Selomangleng No.1, Kediri, Jawa Timur-Indonesia 64115 \\ Email : elferdreno@unik-kediri.ac.id
}

\begin{abstract}
ABSTRAK
Diabetes Melitus merupakan penyakit degeneratif, dengan ciri hiperglikemia akibat kelainan sekresi insulin, kerja insulin atau kedua-duanya. Penelitian ini bertujuan untuk mengetahui perbedaan glukosa serum dan plasma $\mathrm{NaF}$ dengan penundaan $12 \mathrm{jam}$ pada pasien diabetes melitus. Metode yang digunakan cross-sectional, dengan jumlah sampel sebanyak 60 responden, diambil secara purposive sampling. Kadar glukosa serum dan plasma $\mathrm{NaF}$ dengan penundaan 12 jam diperiksa dengan metode GOP-PAP dan sebagai pembanding adalah glukosa serum segera diperiksa. Darah dimasukkan dalam 3 tabung berbeda, darah segera diperiksa, glukosa serum dan plasma NaF dengan penundaan $12 \mathrm{jam}$. Hasil penelitian ditemukan perbedaan glukosa serum dan plasma $\mathrm{NaF}$ dengan penundaan $12 \mathrm{jam}$ pada pasien diabetes melitus $p>0,05(p=0,000$ dan 0,118$)$. Kesimpulan dari penelitian ini ditemukan perbedaan bermakna antara glukosa serum dan plasma $\mathrm{NaF}$ dengan penundaan 12 jam pada pasien diabetes melitus.
\end{abstract}

Kata kunci: Glukosa, Serum, Plasma NaF

\begin{abstract}
Diabetes melitus is a degenerative disease, characterized by hyperglycemia due to abnormal insulin secretion, insulin action or both. This study aims to determine the differences in serum glucose and $\mathrm{NaF}$ plasma with a 12 hour delay in patients with diabetes melitus. The method used is cross sectional, with a total sample of 60 respondents, taken by purposive sampling. Serum glucose levels and plasma $\mathrm{NaF}$ with a 12 hour delay were examined by the GOP-PAP method and as a comparison the serum glucose was checked immediately. Blood is put into 3 different tubes, blood is immediately checked, serum glucose and plasma $\mathrm{NaF}$ with a delay of 12 hours. The results found differences in serum glucose and $\mathrm{NaF}$ plasma with a 12 hour delay in patients with diabetes melitus $\mathrm{p}>0.05(\mathrm{p}=0,000$ and 0,118$)$. The conclusion of this study found significant differences between serum glucose and plasma NaF with a delay of 12 hours in patients with diabetes melitus
\end{abstract}

Keywords: Glucose, Serum, Plasma NaF 


\section{Pendahuluan}

Prevalensi diabetes melitus di dunia meningkat dari 226 juta pada tahun 2011 menjadi 552 juta tahun 2030. Indonesia merupakan negara keempat dengan jumlah kasus diabetes melitus tertinggi di dunia. ${ }^{(1)(2)}$

Diabetes Melitus merupakan penyakit degeneratif, dengan ciri hiperglikemia akibat kelainan sekresi insulin, kerja insulin atau kedua-duanya. ${ }^{(3)}$ Hiperglikemia menyebabkan kerusakan beberapa sistem tubuh seperti kerusakan saraf, kerusakan pembuluh darah, kerusakan ginjal, dan kerusakan jantung. Pemeriksaan glukosa darah untuk diagnostik diabetes melitus (puasa $>126 \mathrm{mg} / \mathrm{dl}$ ). ${ }^{(4)(5)}$

Penundaan pemeriksaan glukosa darah menyebabkan glikolisis pada eritrosit, sel darah putih (WBCs) dan trombosit. Glikolisis terjadi akibat pengaruh suhu, lama penyimpanan, dan kontaminasi bakteri. Faktor glikolisis menyebabkan kadar glukosa menurun dan dapat dicegah dengan pemberian zat penghambat glikolisis. ${ }^{(6)}$ Glikolisis dapat menurunkan kadar glukosa darah 5-7 \% per/jam pada suhu ruangan. ${ }^{(7)}$

Pada beberapa penelitian dilaporkan menggunakan sampel darah utuh didapatkan glukosa darah menurun pada lama penundaan waktu pemeriksaan 24 jam dan penyimpanan pada suhu $>22^{\circ} \mathrm{C}$ dan penelitian berbeda didapatkan hasil penurunan signifikan pada kadar glukosa darah yang disimpan selama 6 jam pada suhu ruangan dengan metode microtest ditemukan penurunan kadar glukosa darah sekitar $36 \mathrm{mg} / \mathrm{L}$ per/jam pada suhu kamar dan suhu kulkas $4^{\circ} \mathrm{C}$ meminimalkan penurunan kadar glukosa darah hingga 3,9 mg/L per/jam ${ }^{(7)}$.
Oleh sebab itu peneliti melakukan penelitian untuk mengetahui perbedaan glukosa serum dan plasma $\mathrm{NaF}$ dengan penundaan 12 jam pada pasien diabetes melitus. Manfaat penelitian ini untuk petugas laboratorium agar pemeriksaan glukosa darah segera diperiksa atau bila tidak segera diperiksa sebaiknya ditambahkan antikoagulan $\mathrm{NaF}$ agar tidak mengalami glikolisis.

\section{Metode Penelitian}

Penelitian ini menggunakan metode rancangan cross-sectional survey yang dilakukan di Rumah Sakit Bhayangkara Kediri bulan Mei Tahun 2017. Populasi penelitian adalah 108 responden dan menggunakan rumus slovin didapatkan 60 responden. Variabel dependen adalah pasien diabaets melitus di rumah sakit Bhayangkara Kediri. Data yang digunakan adalah hasil pemeriksaan laboratorium glukosa darah serum dan plasma $\mathrm{NaF}$ dengan penundaan 12 jam dan sebagai pembanding adalah glukosa darah serum segera diperiksa.

Metode pengumpulan data dilakukan dengan cara purposive sampling dan memenuhi kriteria inklusi dan kriteria esklusi. Kriteria inklusi terdiri dari pasien rawat jalan yang telah didiagnosa diabetes melitus di rumah sakit Bhayangkara Kediri dan pasien yang telah berpuasa 8-10 jam. Kriteria eksklusi meliputi sampel darah pasien diabetes melitus rawat jalan yang hemolisis. Seluruh data dianalisis dengan Statistical Program for Social Sciences (SPSS) menggunakan uji One Way Annova dan uji alternatif Kruskal-Wallis apabila syarat distribusi normal tidak terpenuhi. 


\section{Hasil}

Tabel 1. Distribusi Proporsi Pasien Diabetes Melitus di Rumah Sakit Bhayangkara

\begin{tabular}{lcc}
\hline & $\mathbf{N}$ & Persentase \\
\hline 1. Jenis Kelamin & & \\
Laki-laki & 27 & $45 \%$ \\
Perempuan & 33 & $55 \%$ \\
Total & 60 & $100 \%$ \\
\hline 2. Umur & & \\
31-40 Tahun & 9 & $15 \%$ \\
41-50 Tahun & 15 & $25 \%$ \\
51-60 Tahun & 18 & $30 \%$ \\
61-70 Tahun & 14 & $23 \%$ \\
71-80 Tahun & 4 & $7 \%$ \\
Total & 60 & $100 \%$ \\
\hline
\end{tabular}

Tabel 2. Distribusi Pemeriksaan Glukosa Darah Serum Segera Diperiksa, Glukosa Serum dan Plasma NaF dengan Penundaan pada 12 Jam

\begin{tabular}{lccc}
\hline & Mean & Median & $\begin{array}{c}\text { Std } \\
\text { Deviation }\end{array}$ \\
\hline $\begin{array}{l}\text { Glukosa } \\
\text { serum } \\
\text { segera } \\
\text { diperiksa }\end{array}$ & 197,95 & 173.15 & 188,61 \\
\hline $\begin{array}{l}\text { Glukosa } \\
\text { serum } \\
\text { dengan } \\
\text { penundaan }\end{array}$ & 188,00 & 167,00 & 179,00 \\
\hline $\begin{array}{l}\text { Plasma } \\
\text { NaF } \\
\text { dengan } \\
\text { penundaan }\end{array}$ & 44,97 & 45,48 & 45,48 \\
\hline
\end{tabular}

Tabel 3. Uji Normalitas Glukosa Darah Serum Segera Diperiksa, Glukosa Serum dan Plasma NaF dengan Penundaan 12 Jam

\begin{tabular}{llc}
\hline & $\mathbf{N}$ & $\mathbf{p}$ \\
\hline $\begin{array}{l}\text { Glukosa serum } \\
\text { segera } \\
\text { diperiksa* }\end{array}$ & 60 & 0,003 \\
\hline $\begin{array}{l}\text { Glukosa serum } \\
\text { dengan } \\
\text { penundaan* }\end{array}$ & 60 & 0,003 \\
\hline $\begin{array}{l}\text { Plasma NaF } \\
\text { dengan }\end{array}$ & 60 & 0,000 \\
\hline \multicolumn{2}{c}{$*$ Kolmondaan*orov-Smirnov } \\
\hline
\end{tabular}

Tabel 4. Uji Kruskal-Wallis Glukosa Darah Serum Segera Diperiksa, Glukosa Serum dan Plasma NaF dengan Penundaan 12 Jam

\begin{tabular}{lcc}
\hline & N & p \\
\hline $\begin{array}{l}\text { Glukosa serum } \\
\text { segera } \\
\text { diperiksa }\end{array}$ & 60 & 0,000 \\
\hline $\begin{array}{l}\text { Glukosa serum } \\
\text { dengan } \\
\text { penundaan }\end{array}$ & 60 & 0,000 \\
\hline $\begin{array}{l}\text { Plasma NaF } \\
\text { dengan } \\
\text { penundaan }\end{array}$ & 60 & 0,000 \\
\hline
\end{tabular}

Tabel 5. Uji Mann Whitney Glukosa Darah Serum Segera Diperiksa dan Glukosa Serum dengan Penundaan 12 Jam

\begin{tabular}{lcc}
\hline & N & p \\
\hline $\begin{array}{l}\text { Glukosa serum } \\
\text { segera } \\
\text { diperiksa }\end{array}$ & 60 & 0,000 \\
\hline $\begin{array}{l}\text { Glukosa serum } \\
\text { dengan } \\
\text { penundaan }\end{array}$ & 60 & 0,000 \\
\hline
\end{tabular}

Tabel 6. Uji Mann Whitney Glukosa Darah Serum Segera Diperiksa dan Plasma NaF dengan Penundaan 12 Jam

\begin{tabular}{lcc}
\hline & $\mathrm{N}$ & $\mathrm{p}$ \\
\hline $\begin{array}{l}\text { Glukosa serum } \\
\text { segera } \\
\text { diperiksa }\end{array}$ & 60 & 0,118 \\
\hline $\begin{array}{l}\text { Plasma NaF } \\
\text { dengan } \\
\text { penundaan }\end{array}$ & 60 & 0,118 \\
\hline
\end{tabular}

\section{Pembahasan}

Berdasarkan hasil penelitian di atas didapatkan penderita diabetes melitus terbanyak adalah perempuan $(55 \%)$ (Tabel 1). Penelitian yang dilakukan Trisnawati dkk tahun 2013 wanita mengalami peningkatan indeks masa tubuh, sindrom siklus bulanan (Premenstrual syndrome), pasca menopause yang mempercepat distribusi lemak tubuh akibat proses hormonal yang membuat wanita berisiko menderita diabetes melitus. ${ }^{(2)}$ 
Hasil penelitian menunjukkan bahwa penderita diabetes melitus terbanyak merupakan kelompok umur 51 - 60 tahun (30\%) (Tabel 1). Penelitian yang dilakukan Rahayu dkk tahun 2013 menyatakan penurunan fungsi fisiologis manusia terjadi setelah berumur 40 tahun. Risiko mengidap diabetes melitus akan meningkat saat berusia $\geq 45$ tahun (kelompok risiko tinggi). ${ }^{(8)}$

Berdasarkan hasil penelitian glukosa serum segera diperiksa dengan glukosa serum penundaan dan glukosa segera diperiksa dengan plasma $\mathrm{NaF}$ penundaan, didapatkan nilai $\mathrm{p}=$ 0,000 dan $\mathrm{p}=0,118$ (Tabel 5 dan Tabel 6). Terdapat perbedaan yang bermakna antara glukosa serum segera diperiksa dan plasma $\mathrm{NaF}$ dengan penundaan 12 jam pada pasien diabetes melitus. Penelitian yang dilakukan Agung tahun 2017 menyatakan pemeriksaan glukosa darah menggunakan antikoagulan $\mathrm{NaF}$ dapat menghambat glikolisis. ${ }^{(9)}$

Penundaan pemeriksaan glukosa darah menyebabkan glikolisis 5 - 7 \% kadar glukosa darah sampel per jam. Pemeriksaan glukosa darah yang ditunda dapat disebabkan terhambatnya pengiriman sampel ke laboratorium, keterbatasan tenaga analis, alat dan bahan. Sampel darah diberikan antikoagulan natrium fluorida $(\mathrm{NaF})$ yang dapat mencegah proses glikolisis akibat penundaan pemeriksaan. ${ }^{(9)}$

\section{Kesimpulan dan Saran}

Dari hasil penelitian didapatkan antikoagulan $\mathrm{NaF}$ efektif untuk pemeriksaan glukosa darah yang mengalami penundaan yang dapat mencegah terjadinya glikolisis.

\section{Daftar Pustaka}

1. International Diabetes Federation. IDInternational Diabetes Federation. (2011). IDF Diabetes Atlas 5th edition. Media. https://doi.org/10.1007/978-90481-3271-3F Diabetes Atlas 5th edition [Internet]. Media. 2011. 20-26 p. Available from: https://www.idf.org/elibrary/epidemiology-research/diabetesatlas.html

2. Trisnawati SK, Setyorogo S. Faktor Risiko Kejadian Diabetes Melitus Tipe II Di Puskesmas Kecamatan Cengkareng Jakarta Barat Tahun 2012. J Ilm Kesehat. 2013;

3. Sirait AM, Bogor K, Kohor S, Faktor P, Sirait AM, Sulistiowati E, et al. Insiden Dan Faktor Risiko Diabetes Melitus Pada Orang Penyakit Tidak Menular ( Incident and Risk Factor of Diabetes Mellitus in Adults at Bogor . Prospective Cohort Study Risk Factors Non Comunicable Diseases ). Bul Penelit Sist Kesehat. 2015;18(2):151-60.

4. Putri N, Isfandiari M. Hubungan Empat Pilar Pengendalian Dm Tipe 2 dengan Rerata Kadar Gula Darah. J Berk Epidemiol. 2013;

5. Setiawan M. Pre-Diabetes Dan Peran Hba1c Dalam Skrining Dan Diagnosis Awal Diabetes Melitus. Saintika Med. 2012;

6. Putra AL, Wowor PM, Wungouw HIS. Gambaran Kadar Gula Darah Sewaktu Pada Mahasiswa Angkatan 2015 Fakultas Kedokteran Universitas Sam Ratulangi Manado. J e-Biomedik. 2015; 
7. Santi OD, Rosita L, Cahyaningrum YD. Pengaruh Suhu dan Interval Waktu Penyimpanan Sampel Serum pada Pengukuran Kadar Glukosa Darah. Jkki. 2011;3(8):39-40.

8. Rahayu P, Utomo M, Setiawan MR. Hubungan Antara Faktor Karakteristik, Hipertensi dan Obesitas dengan Kejadian Diabetes Mellitus di Rumah
Sakit Umum Daerah Dr. H. Soewondo Kendal. J Kedokt Muhammadiyah. 2012;

9. Agung A RD. Perbedaan Kadar Glukosa Serum Dan Plasma Natrium Fluorida (Naf) Dengan Penundaan Pemeriksaan. J Kedokt Diponegoro. 2017; 